\title{
Seasonal variation in phytotoxicity of Drimys brasiliensis Miers
}

\author{
Variación estacional en la fitotoxicidad de Drimys brasiliensis Miers
}

\author{
Simoni Anese ${ }^{1}$, Patrícia Umeda Grisi ${ }^{1}$, Luciana de Jesus Jatobá ${ }^{1}$, Maristela Imatomi ${ }^{1}$, \\ Viviane de Cassia Pereira ${ }^{1}$, Sonia Cristina Juliano Gualtieri ${ }^{1 *}$
}

\begin{abstract}
Drimys brasiliensis Miers (Winteraceae), commonly called casca d'anta, is found in the Atlantic Forest and in Cerrado domain. It is considered an important source of natural compounds with pharmacological properties, however little is known about their phytotoxic potential on other plants. This study aims to evaluate the phytotoxic effects of $D$. brasiliensis leaf extracts collected in two seasons (dry and rainy) on the germination and seedling growth of Sesamum indicum L., as well as evaluating the effect of the most active extract on metaxylem cell size in the roots of the target species. The aqueous extract was prepared with $10 \mathrm{~g}$ of dried, ground leaves dissolved in $100 \mathrm{~mL}$ of distilled water, resulting in a $10 \%$ extract concentrate. Dilutions were made with distilled water to $7.5 ; 5.0 ; 2.5 \%$ and $0 \%$ (control). The leaf extracts showed phytotoxicity on germination and early growth of sesame, with more pronounced activity in leaves collected in the dry season. The inhibitory effects were observed at the cellular level in sesame roots, with a significant reduction in the size of the metaxylem cells in the presence of all concentrations of leaf extract. The extract from leaves of $D$. brasiliensis may constitute a promising source in the search for natural phytotoxins for use in sustainable agriculture practices.
\end{abstract}

Key words: inhibition, seasonality, germinability, metaxylem, sesame.

\section{RESUMEN}

Drimys brasiliensis Miers (Winteraceae), conocida popularmente como "casca-de-anta", se encuentra en formaciones de la Mata Atlántica y del Cerrado en Brasil. Se la considera una importante fuente de compuestos naturales con propiedades farmacológicas, aunque poco se sepa sobre su potencial fitotóxico sobre otras plantas. El objetivo de este trabajo fue evaluar el efecto fitotóxico de hojas de Drimys brasiliensis Miers colectadas en dos estaciones del año (estación seca y húmeda) sobre la germinación y crecimiento de Sesamum indicum L. (sésamo). Además se evaluó el efecto del extracto más activo sobre el tamaño medio de las células del metaxilema de las raíces de sésamo destinataria. El extracto acuoso fue preparado en proporción de $10 \mathrm{~g}$ de material vegetal (polvo) para $100 \mathrm{~mL}$ de agua destilada, logrando la concentración de 10\%. Desde esta concentración inicial, fueron preparadas diluciones en agua destilada para concentraciones de 7.5; 5.0; $2.5 \%$ y $0 \%$ (control). Los extractos de hojas de D. brasiliensis presentaron fitotoxicidad sobre todos los parámetros de germinación y crecimiento inicial del sésamo, con actividad más evidente de las hojas colectadas al final de la estación seca. El efecto inhibitorio pudo ser observado en nivel celular en las raíces del sésamo, con reducción significativa en el tamaño medio de las células del metaxilema en la presencia de todas las concentraciones del extracto foliar. El extracto de las hojas de D. brasiliensis puede constituir una fuente prometedora en la búsqueda de fitotoxinas naturales para utilización en prácticas de agricultura sostenible.

Palabras clave: inhibición, estacionalidad, germinabilidad, metaxilema, sésamo.

\section{Introduction}

Plants produce a vast number of secondary metabolites, compounds that are not directly involved in primary processes of basic growth and development. Many plant natural products play an important role in the interaction of plants with their environment, in particular with their biotic environment, where they may serve as attractants for pollinators or seed dispersers, in defense against natural enemies or as allelochemicals against other plant competitors (Kroymann, 2011).

Production of secondary metabolites may vary among species, plant organs and development stages and is strongly influenced by environmental factors (Gobbo-Neto and Lopes, 2007). The synthesis

\footnotetext{
1 Universidade Federal de São Carlos, Departamento de Botânica, Rodovia Washington Luiz, Km 235, São Carlos, SP, Brasil. CEP 13565-905.

* Corresponding author: dscp@ufscar.br
}

Fecha de Recepción: 3 Marzo, 2014.

Fecha de Aceptación: 23 Junio, 2014. 
of different classes of secondary metabolites in response to environmental factors is part of an adaptive strategy that allows tolerance to biotic and abiotic stresses (Ramakrishna and Ravishankar, 2011). Studies have shown changes in the amount, composition and expression of biological activities of plant secondary metabolites associated with seasonal variations (Castelo et al., 2012, Jemâa et al., 2012). The knowledge of these variations allows the definition of periods wherein some constituents are in greater proportion in the plant, which may be related to different physiological demands associated with defenses against enemies and reproduction (Darrow and Bowers, 1997), as well as contributing to the knowledge of the ecological interactions of plants with their environment.

Allelopathy, as a phenomenon of the interactions between plants and other nearby organisms mediated by chemical agents, constitutes a valuable source of natural products with potential use in the agrochemical industry (Macías et al., 2008). Species with phytotoxic properties can be used in different ways for ecological management in agriculture. Allelochemicals present in plant tissues can be extracted with water and used successfully, as aqueous extracts, for weed and insect pest management (Jabran et al., 2010). Moreover, pure allelochemicals isolated from plants are reported as promising for direct use in weed control or for the formulation of natural herbicides (Dayan et al., 2009). Thus, the identification of plants with phytotoxic properties of their secondary metabolites may contribute to the expansion of scientific knowledge within the context of a more sustainable agriculture that respects the environment and values biodiversity.

Drimys brasiliensis Miers (Winteraceae), commonly called casca d' anta, is a Brazilian shrub or tree that flowers with more intensity from July to August, in the Atlantic Forest from southern Bahia to Rio Grande do Sul states, and in the Cerrado domain (Ehrendorfer et al., 1979). Compounds isolated from the leaves and stem bark of $D$. brasiliensis include drimane sesquiterpenes, monoterpenes and flavonoids (Mecchi and Lago et al., 2013; Limberger et al., 2007; Malheiros et al., 2005). Studies on the biological activities of these constituents have been focused specifically on pharmacological properties (Claudino et al., 2013; Malheiros et al., 2005).

The present study aimed to evaluate the variation of the phytotoxic activity of aqueous extracts of the leaves of Drimys brasiliensis Miers according to seasonal variation, using germination and early growth bioassays with the target species Sesamum indicum L. (sesame). In addition, the size of metaxylem cells in sesame seedling roots was evaluated.

\section{Material and Methods}

\section{Collection of plant material and preparation of extracts}

Mature leaves of $D$. brasiliensis subsp. brasiliensis were collected from individuals of in the reserve area of Cerrado "sensu strictu" on the campus of São Carlos Federal University (UFSCar) in São Carlos-SP (22 $02^{\prime}$ S and $\left.47^{\circ} 52^{\prime} \mathrm{W}\right)$, Brazil. The region is characterized by the Aw climate type (Köppen, 1948), with dry winters (April to September) and wet summers (October to March). A voucher specimen (8339) was deposited in the Herbarium of the Department of Botany of the São Carlos Federal University (HUFSCar). Mature leaves were collected in April (end of dry season) and September (end of rainy season) of 2010 and the plants were in vegetative and reproductive stages (end of flowering), respectively.

After collection, the leaves were dried in an oven with forced air circulation at $40{ }^{\circ} \mathrm{C}$ for $72 \mathrm{~h}$. Later they were ground in an electric grinder, weighed, vacuum packaged in plastic bags and stored at $4{ }^{\circ} \mathrm{C}$. From the dry plant material (powder) of leaves collected at the end of the dry and rainy seasons treatment extracts were produced, which consisted of distilled water and powder at a ratio of $10 \%$ weight/volume $(\mathrm{g} / \mathrm{mL})$. The extracts were left to stand in the dark for $24 \mathrm{~h}$ at $4{ }^{\circ} \mathrm{C}$ and then vacuum filtered, using an electric pump coupled to a Buchner funnel lined internally with filter paper. The resulting solutions (10\% extracts) were diluted to concentrations of 10.0, 7.5, 5.0, 2.5 and $0 \%$ (control).

To verify the variation of the phytotoxic effect at different collection periods, Sesamum indicum L. (Pedaliaceae) was used as the target species. Phytotoxic effects were evaluated through bioassay of seed germination and initial growth of seedlings. In addition, we evaluated the effect of the most active extract on metaxylem cell growth in roots of sesame seedlings. 


\section{Osmotic potential and $\mathrm{pH}$ of the extracts}

The $\mathrm{pH}$ of the extracts was measured with an Analion pH meter, Model PM608, and the molar concentration with an automatic osmometer ( $\mu$ Osmotte, model 5004). The osmotic potentials of the most concentrated leaf extracts $(10 \%)$ were calculated. To assess the osmotic effect of the extracts bioassays of germination and growth were performed with sesame using solutions of polyethylene glycol 6000 (PEG 6000) at $-0.26 \mathrm{MPa}$, and the control (0 $\mathrm{MPa})$. The experiments were performed adopting the same methodology described for the germination and growth bioassays.

\section{Germination bioassay}

Bioassays were conducted in Petri dishes of $90 \mathrm{~mm}$ diameter containing two sheets of filter paper moistened with distilled water (control) or different concentrations of the extracts obtained from the powder of $D$. brasiliensis leaves. Each plate received 25 seeds of sesame, with four replicates for each extract, then was capped and sealed with plastic film. The experiment was conducted in a germination chamber at $25^{\circ} \mathrm{C}$, under a photoperiod of $12 \mathrm{~h}$ light/12h dark. The experimental design was completely randomized. The germination criterion was based on embryo protrusion, which was evaluated at intervals of 24 hours thereafter until the stabilization of germination. The germinability, mean germination time and rate (Maguire's index) were calculated according to Ranal and Santana (2006).

\section{Seedling growth bioassay}

To standardize the size of the plants in the growth bioassay about 50 target plant seeds were germinated in Petri dishes of $15 \mathrm{~mm}$ diameter, containing filter paper moistened with distilled water. Plates were capped, wrapped with plastic film and put in a germination chamber under the same conditions adopted for the germination tests. Seedlings with $3 \mathrm{~mm}$-long roots were selected and transferred to transparent plastic boxes $(15 \times 10 \times 5 \mathrm{~cm})$. The boxes were lined with two sheets of filter paper moistened with $8 \mathrm{~mL}$ of different concentrations of aqueous extracts of $D$. brasiliensis and distilled water (control), totaling 10 seedlings per box, with four replications for each treatment. The boxes were capped and kept under the same conditions mentioned for the germination bioassay. After seven days, the shoot and primary root lengths of the seedlings were measured using a digital caliper.

\section{Examination of metaxylem cells}

For this test, $S$. indicum seedlings grown in the presence of control and aqueous extract of $D$. brasiliensis leaves with greater activity in the same conditions adopted for the growth bioassay at concentrations of 2.5, 5.0 and $7.5 \%$. After four days, the primary root segments of the seedlings were removed and immersed in $70 \%$ alcohol. The modified Fuchs staining method was used (Kraus and Arduin, 1997), where the roots were immersed in alcohol (70\%) for five days and placed in a solution of $25 \% \mathrm{NaOH}$ at $60^{\circ} \mathrm{C}$ for 48 hours, until the material was clarified. Then the root segments were immersed in safranin $\left(\mathrm{C}_{20} \mathrm{H}_{19} \mathrm{~N}_{4} \mathrm{C}_{1}\right)$ and caustic soda $(10 \% \mathrm{NaOH})$ for 24 hours at $60{ }^{\circ} \mathrm{C}$. After staining the material was mounted on glass slides in Apathy's syrup (Kraus and Arduin, 1997) with the roots, for observation under an optical microscope (Olympus-BX41) coupled to a camera (Sony CCDIRIS). We used four replicates of primary roots grown in different concentrations of the extract and control. Half of the length of each root from the central region upward was photographed. From each photograph, 15 central cells of the metaxylem were measured at 20X magnification (Image Pro Plus program) (Gatti et al., 2010).

\section{Statistical Analysis}

The data were subjected to normality (ShapiroWilk) and homogeneity (Levene) tests. When these two assumptions were met, an analysis of variance (ANOVA) was applied. The linear or quadratic regression models were adjusted when the ANOVA $F$ was significant. The goodness of the models was tested at 0.05 significance and evaluated by the coefficient of determination $\left(\mathrm{R}^{2}\right)$. For the variables that showed no significant differences between treatments, the means were represented in the figures with their standard errors. To compare the effects of collection periods, the linear regression equations were submitted to the parallelism ( $F$-test) test to verify the null hypothesis that the slopes of the equations were statistically equal, as described by Sokal and Rohlf (1997). 


\section{Results and Discussion}

The D. brasiliensis extracts from leaves collected in the rainy and dry season significantly inhibited the germination and growth process in sesame. Under the influence of leaves collected in the rainy season a linear decrease in germination was observed $(0.188 \%$ for each addition of $0.01 \mathrm{~g} /$ $\mathrm{mL}^{-1}$ of extract), a linear increase in the mean germination time ( 0.0177 days for each addition of $0.01 \mathrm{~g} / \mathrm{mL}^{-1}$ of extract) and decline in Maguire's index $\left(0.056\right.$ seeds hour ${ }^{-1}$ for each $0.01 \mathrm{~g} / \mathrm{mL}^{-1}$ of extract). Similarly, under the effects of leaves collected in the dry season a linear decrease in germination was also observed $(3.84 \%$ for each $0.01 \mathrm{~g} / \mathrm{mL}^{-1}$ of extract added), increase in mean germination time $(0.031$ days for each addition of $0.01 \mathrm{~g} / \mathrm{mL}^{-1}$ of extract) and consequent reduction in Maguire's index $\left(0.068\right.$ seeds hour $^{-1}$ for each $0.01 \mathrm{~g} / \mathrm{mL}^{-1}$ of extract) (Figure 1).

In both collection seasons all of the germination process variables of sesame were affected by the aqueous extracts of $D$. brasiliensis. Often, the allelopathic effect is not only on germination, but also on the germination speed or other characteristics of the process, highlighting the influence of allelopathic phytotoxins in the metabolism of seeds (Ferreira and Aquila, 2000). Previous work showed that the germination of sesame seeds was not affected by aqueous extracts of donor plants such as Jatropha curcas L. (Rejila and Vijayakumar, 2011) and Aristolochia esperanzae Kuntze (Gatti et al., 2010). Unlike these studies, the aqueous extracts of D. brasiliensis affected the germination of sesame seeds, indicating that this species may contain compounds with high phytotoxic potential in the leaves.
In the analysis of sesame seedling growth, root length was significantly inhibited by leavf extracts, with null values at estimated concentrations of 7.2 and $3.6 \%$, respectively, for the rainy and dry season. Regarding shoot growth, there was a linear reduction in the final length of this organ $(0.718 \mathrm{~mm}$ for rainy and $1.02 \mathrm{~mm}$ for dry season for each addition of $0.01 \mathrm{~g} / \mathrm{mL}^{-1}$ of extract) (Figure 1). Aqueous extracts of leaves from other donor plants also affected sesame seedling growth, mainly by reducing root length, with concentration-dependent effects (Gatti et al., 2010; Rejila and Vijayakumar, 2011).

According to Ferreira and Aquila (2000) the inhibition produced on root development is one of the main factors that indicate sensitivity of the plant to the effects of allelopathic phytotoxins. Yoshimura et al. (2011) argue that the primary root surface is more permeable to phytotoxins in comparison to the hypocotyl surface due to the presence of a less pronounced protective cuticle layer on the primary root, which can result in greater penetration and concentration of these compounds into the root tissue.

Comparison of linear regressions indicated that Maguire's index of sesame seeds showed the same rate of decline in both collection seasons, whereas the germinability, mean germination time and shoot growth were significantly more influenced by leaf extract obtained from the collection in the dry season (Table 1).

A variation in phytotoxicity of aqueous extracts of $D$. brasiliensis related to the collection season was observed, with more evident activity found in the leaves collected in the dry season. The production of secondary metabolites (allelochemicals) in plants is influenced by several factors such as phenology, circadian rhythms, mineral resource disposition,

Table 1. F-test comparing the linear regression angular coefficients derived from the germination and growth of sesame subjected to the action of leaf extracts of $D$. brasiliensis collected in the rainy and dry season.

\begin{tabular}{lcc}
\hline \multicolumn{1}{c}{ Measurement (unit) } & Equation ${ }^{1}$ & $\mathrm{~F}_{\text {calculated }}$ \\
\hline Germinability (\%) & $\mathrm{y}=96.8-0.188 \mathrm{x}$ & $9.42 *$ \\
& $\mathrm{y}=100.8-3.84 \mathrm{x}$ & $31.27 *$ \\
Mean germination time (day) & $\mathrm{y}=0.9289+0.0177 \mathrm{x}$ & \\
& $\mathrm{y}=0.9085+0,0318 \mathrm{x}$ & $3.74^{\mathrm{ns}}$ \\
Maguire's index (seed hour $^{-1}$ ) & $\mathrm{y}=0.9099-0.056 \mathrm{x}$ & $6.10 *$ \\
& $\mathrm{y}=0.8546-0.068 \mathrm{x}$ \\
Shoot lenght $(\mathrm{mm})$ & $\mathrm{y}=10.466-0.7182 \mathrm{x}$ & \\
\end{tabular}

${ }^{1} \mathrm{H} 0: \beta 1-\beta 2=0$, where $\beta 1$ and $\beta 2$ are the parameters of the angular coefficients of the equations. ' $y$ : rainy season; $y$ : dry season. ns: angular coefficients for the two seasons do not differ significantly. *angular coefficients for the two species differ significantly (Fcalculated $>$ Ftabulated). 

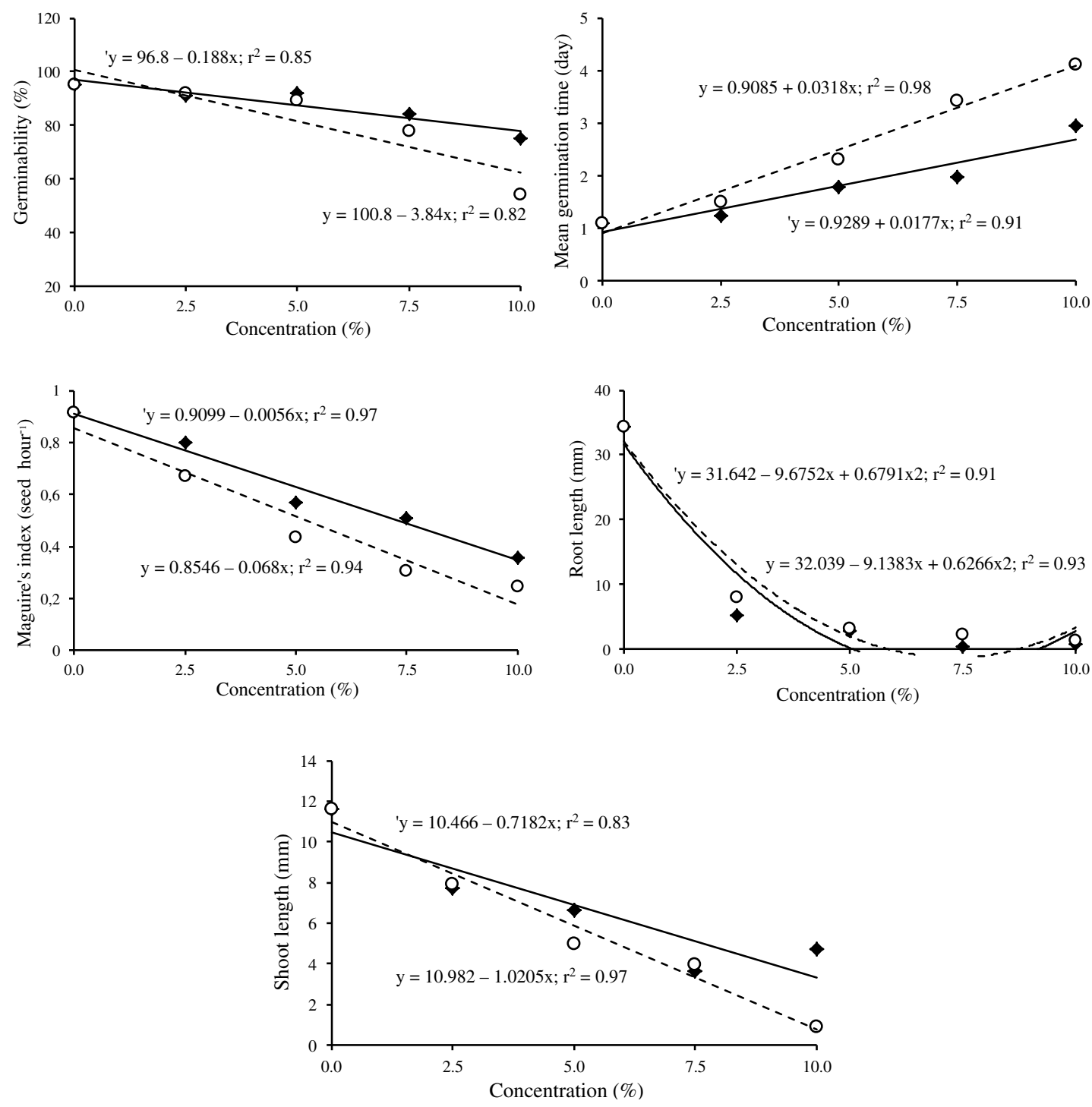

$\bullet$ rainy season ('y) $\quad$ o dry season (y)

Figure 1. Germinability, mean germination time, Maguire's index, root and shoot length of sesame subjected to the action of different leaf extract concentrations of $D$. brasiliensis collected in the rainy and dry seasons.

temperature, UV radiation, osmotic stress (drought and salinity) and seasonal variation (Ramakrishna and Ravishankar, 2011; Gouvea et al., 2012). Seasonal variation involves abrupt changes in temperature and soil moisture, causing deviations of biosynthetic pathways of primary and secondary metabolites (Taiz and Zeiger, 2006). Many studies have reported changes in the content of secondary metabolites during different seasons, especially the greater accumulation of phytotoxins and expression of biological activities in the dry season (Jemâa et al., 2012; Castelo et al., 2012; Sahoo et al., 2012).

The accumulation of secondary metabolites often occurs in plants subjected to biotic and abiotic stresses (Ramakrishna and Ravishankar, 2011). In the Cerrado, where D. brasiliensis was collected, the seasonal water deficits present in the surface layer of its oligotrophic soil (Haridasan, 2001) could result in a greater amount of allelochemicals. Castelo et al. (2012) showed that the Cerrado dry season 
led to an increase in the production of essential oils in Blepharocalyx salicifolius (Kunth) O. Berg and Psidium myrsinites Mart. ex DC. However, other studies claim that seasonal effects may be dependent on the species. In leaves of Eremanthus mattogrossensis Kuntze, Gouvea et al. (2012) found a strong correlation between higher concentrations of flavonoids and caffeoylquinic acid and the rainy season in the Cerrado.

The phenological stage of the donor plant also exerts influence in inducing the production of allelochemicals and their cost to the plant (Çirak et al., 2008). The vegetative phase of $D$. brasiliensis occurs in the rainy season, while the reproductive phase coincides with the dry season in the Cerrado. The energy investment for the production of protection metabolites of seeds may be higher in the reproductive periods, ensuring reproduction success. Çirak et al. (2008) and Hosni et al. (2011) observed that the stage of development influences the biosynthesis of plant secondary metabolites, with an increase during the flowering periods.

The anatomical study of sesame roots allowed a better visualization of the phytotoxic effects of leaf extracts (collected in the dry season) at the cellular level. The roots grown in the presence of different leaf extract concentrations displayed a more pronounced reduction in the average size of the metaxylem cells compared to those grown in the control solution (Figure 2). The average size of the control cells was $137.9 \mu \mathrm{m}$, three times higher than recorded for cells grown at an extract concentration of $7.5 \%$, which was $37.8 \mu \mathrm{m}$.

The cell size class distribution of the control group was homogenous, with the highest percentage (27.5\%) observed for cells between 120-140 $\mu \mathrm{m}$ in length. There were no cells smaller than $80 \mu \mathrm{m}$ in the control group (Figure 3A). The metaxylem cells of seedlings grown under the influence of the leaf extracts at concentrations of 2.5 and $5.0 \%$ showed predominance in size between $40-60 \mu \mathrm{m}$ (Figure 3B;C), whereas at a concentration of $7.5 \%$, $52 \%$ of the cells had sizes between $20-40 \mu \mathrm{m}$. There were no cells greater than $100 \mu \mathrm{m}$ in the extract concentration of $7.5 \%$ (Figure 3D). Cell measurements at a concentration of $10 \%$ were not possible, since there was complete inhibition of root growth in this condition.

The reduction in S. indicum root growth caused by the leaf extract of $D$. brasiliensis may be associated with the inhibition of cell elongation, as observed here for metaxylem cells, suggesting possible interference of phytotoxins in the concentration balance of phytohormones such as auxin, cytokinin and ethylene. The synergistic interaction of these hormones is critical in the regulation of primary root cell elongation, lateral root formation, vascular tissue differentiation and primary root growth

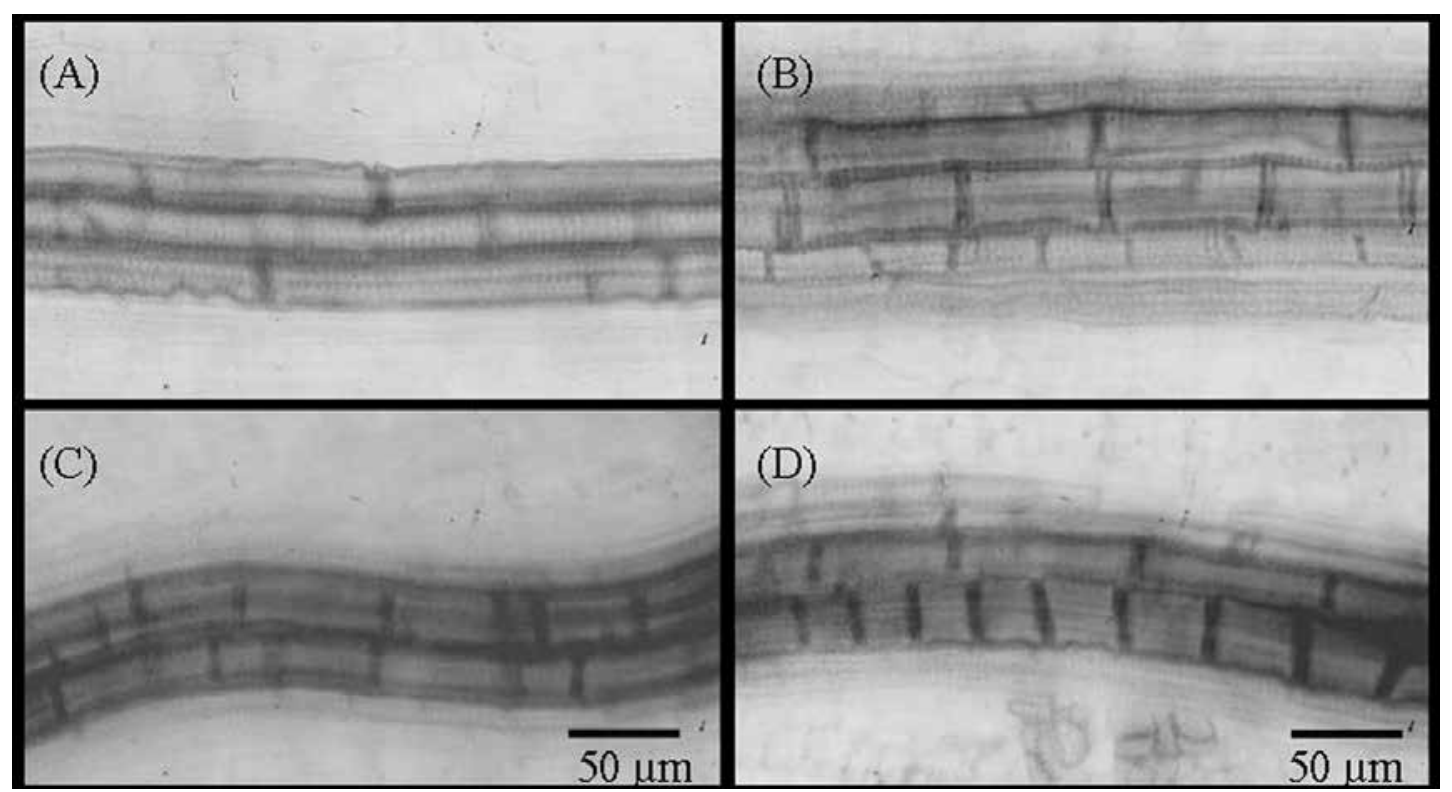

Figure 2. Photomicrographs of root metaxylem cells of Sesamum grown in control (A) and at concentrations of $0.25 \%$ (B), $5.0 \%$ (C) and $7.5 \%$ (D) of leaf extract from D. brasiliensis. 

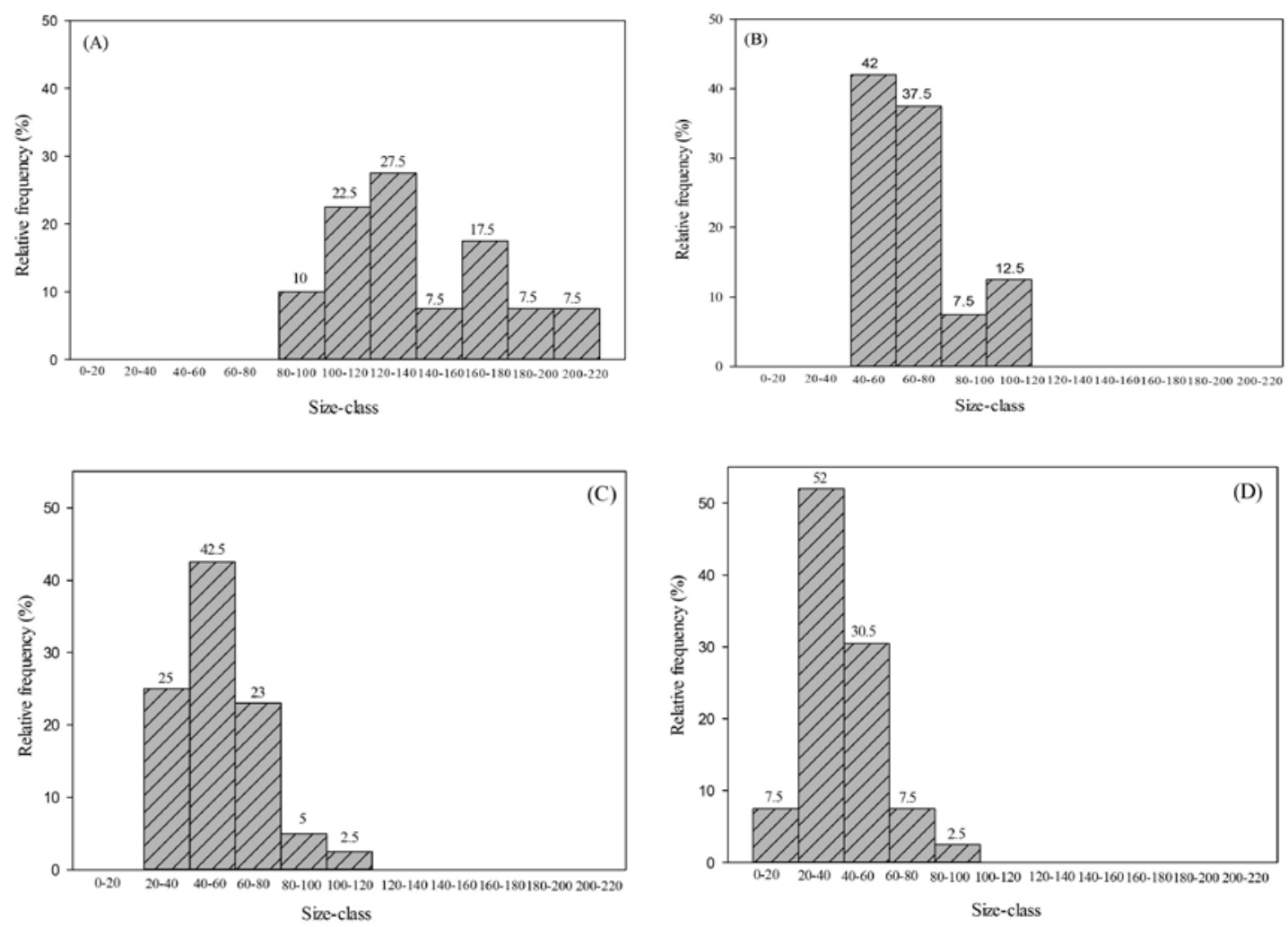

Figure 3. Size class $(\mu \mathrm{m})$ of the relative frequency of root metaxylem cells of sesame seedlings grown in control (A) and concentrations of $2.5 \%$ (B), $5.0 \%$ (C) and $7.5 \%$ (D) of extract of D.brasiliensis leaves.

(Aloni et al., 2006). Aqueous extracts of leaves of Aristolochia esperanzae also interfered with metaxylem cell development in roots of $S$. indicum (Gatti et al., 2010). The authors suggest that the interference of allelochemicals in reducing the size of the cells may be associated with changes in the concentration of phytohormones. It is known that plant allelopathic phytotoxins may interfere with the activity of enzymes involved in the biosynthetic pathway of auxin and its specific transport proteins, as demonstrated by Prasad and Subhashini (1994).

The aqueous extract from leaves collected in the dry season had a $\mathrm{pH}$ of 4.18. Considering that germination and seedling development are negatively affected by conditions of extreme acidity or alkalinity, the $\mathrm{pH}$ of leaf extracts from $D$. brasiliensis does not interfere with these processes. The osmotic potential of the aqueous extract of leaves was $-0.26 \mathrm{MPa}$. In this potential the sesame seeds showed $96 \%$ germination, and the average root and shoot growth was 27.3 and $12.7 \mathrm{~mm}$, respectively. These data did not differ from those obtained for the control group, thus we can infer that the reduction in the germinability and early growth of sesame occurred specifically as a result of the presence of allelopathic phytotoxins in the aqueous leaf extracts of $D$. brasiliensis. Drimane sesquiterpenes, aromadendranes, monoterpenes and flavonoids are secondary metabolites reported in $D$. brasiliensis (Mecchi and Lago et al., 2013; Claudino et al., 2013; Limberger et al., 2007; Malheiros et al., 2005 ) and they may be involved with the phytotoxic activity observed for this species. However, further studies are necessary to identify the compounds responsible for the observed effects.

\section{Conclusions}

Leaf extracts of $D$. brasiliensis showed phytotoxicity on germination and early growth of sesame, with more pronounced activity in leaves collected in the dry season. Inhibitory effects were observed at the cellular level in sesame roots, with a significant reduction in metaxylem cell size.

\section{Acknowledgements}

The authors would like to thank the CAPES and CNPq for financial support. 


\section{Literature Cited}

Aloni, R.; Aloni, E.; Langhans, M.; Ullrich, C.I.

2006. Role of cytokinin and auxin in shaping root architecture: regulating vascular differentiation, lateral root initiation, root apical dominance and root gravitropism. Annals of Botany, 97 (5): 883-893.

Castelo, A.V.M.; Del Menezzi, C.H.S.; Resck, I.S.

2012. Seasonal variation in the yield and the chemical composition of essential oils from two Brazilian natives arbustive species. Journal of Applied Science, 12 (8): 753-760.

Çirak, C.; Radusiene, J.; Camass, N.

2008. Pseudohypericin and hyperforin in two Turkish Hypericum species: variation among plant parts and phonological stages. Biochemical Systematics and Ecology, 36 (5): 377-382.

Claudino, V.D.; Silva, K.C.; Cechinel Filho, V.; Yunes, R.A.; Delle Monache, F.; Giménez, A.; Salamanca, E.; GutiérrezYapu, D.; Malheiros, A

2013. Drimanes from Drimys brasiliensis with leishmanicidal and antimalarial activity. Memórias do Instituto Oswaldo Cruz, 108 (2): 140-4.

Darrow, K.; Bowers, M.D.

1997. Phenological and population variation in iridoid glycosides of Plantago lanceolata (Plantaginacaeae). Biochemical Systematics and Ecology, 25 (1): 1-11.

Dayan, F.E.; Cantrell, C.L.; Duke, S. O.

2009. Natural products in crop protection. Bioorganic and Medicinal Chemistry, 17 (12): 4022-4034.

Ehrendorfer, F.; Gottsberger, I.S.; Gottsberger, G.

1979. Variation on the population, racial, and species level in the primitive relic angiosperm genus Drimys (Winteraceae) in South America. Plant Systematics and Evolution, 132 (1-2): 53-83.

Ferreira, A.G.; Áquila, M.E.A.

2000. Alelopatia: uma área emergente da ecofisiologia. Revista Brasileira de Fisiologia Vegetal, 12 (1): 175-204.

Gatti, A.B.; Ferreira, A. G.; Arduin, M.; Pérez, S. C. J. G. A. 2010. Allelopathic effects of aqueous extracts of Aristolochia esperanzae O.Kuntze on development of Sesamum indicum L. seedlings. Acta Botânica Brasílica, 24 (2): 454-461.

Gobbo-Neto, L.; Lopes, N.P.

2007. Plantas medicinais: fatores de influência no conteúdo de metabólitos secundários. Química Nova, 30 (2): 374-381.

Gouvea, D.R.; Gobbo-Neto, L.; Sakamoto, H.T.; Lopes, N.P.;

Lopes, J.L.C.; Meloni, F.; Amaral, J.C.

2012. Seasonal variation of the major secondary metabolites present in the extract of Eremanthus mattogrossensis Less (Asteraceae: Vernonieae) leaves. Química Nova, 35 (11): 2139-2145.

Haridasan, $\mathrm{M}$.

2001. Nutrient cycling as a function of landscape and biotic characteristics in the Cerrado of central of central Brazil. pp. 68-83. In: Mcclain, M.E.; Victoria, R.L.; Richey, J.E. (ed). Biogeochemistry of the Amazon basis and its role in a changing world. New York, Oxford University Press.

Hosni, K.; Msaadab, K.; Taâritb, M.B.; Marzoukb, B. 2011. Phenological variations of secondary metabolites from Hypericum triquetrifolium Turra. Biochemical Systematics and Ecology, 39 (1): 43-50.

Jabran, K.; Farooq, M.; Hussain, M.; Rehman, H.U.; Ali, M.A. 2010. Wild oat (Avena fatua L.) and canary grass (Phalaris minor Ritz.) management through allelopathy. Journal of Plant Protection Research, 50 (1): 41-45.
Jemâa, J.M.B.; Haouela, S.; Bouazizb, M.; Khoujac, M.L.

2012. Seasonal variations in chemical composition and fumigant activity of five Eucalyptus essential oils against three moth pests of stored dates in Tunisia. Journal of Stored Products Research, 48 (1): 61-67.

Limberger, R.P.; Scopel, R.; Sobral, M.; Henriques, A.T.

2007. Comparative analysis of volatiles from Drimys brasiliensis Miers and D. angustifolia Miers (Winteraceae) from Southern Brazil. Biochemical Systematics and Ecology, 35 (3): 130-137.

Kroymann, J.

2011. Natural diversity and adaptation in plant secondary metabolism. Current Opinion in Plant Biology, 14 (3): 246-251.

Kraus, J.E., Arduin, M.

1997. Manual básico de métodos em morfologia vegetal. Seropedica, EDUR, 198 pp.

Köppen, W.

1948. Climatologia: com um estúdio de los climas de la tierra. México: Fondo de Cultura Econômica, 479 pp.

Macías, F.A.; Oliveros-Bastidas, A.; Marín, D.; Carrera, C.;

Chinchilla, N.; Molinillo, J.M.G.

2008. Plant biocommunicators: their phytotoxicity, degradation studies and potential use as herbicide models. Phytochemistry Review, 7 (1): 179-194.

Malheiros, A.; Cechinel Filho, V.; Schmitt, C.B.; Yunes, R.A.;

Escalante, A.; Svetaz, L.; Zacchino, S.; Delle Monache, F. 2005. Antifungal activity of drimane sesquiterpenes from Drimys brasiliensis using bioassayguided fractionation. Journal of Pharmaceutical Sciences, 8 (2): 335-339.

Mecchi, M.C.; Lago, J.H.G.

2013. Chemical constituents derived from Drimys brasiliensis Miers (Winteraceae). Natural Product Research, 27 (20): 1927-1929.

Prasad, M.N.V.; Subhashini, P.

1994. Mimosine-inhibited seed germination, seedling growth, and enzymes of Oryza sativa L. Journal of Chemical Ecology, 20 (7): 1689-1696.

Ramakrishna, A.; Ravishankar, G.A.

2011. Influence of abiotic stress signals on secondary metabolites in plants. Plant Signaling \& Behavior, 6 (11): 1720-1731.

Ranal, M.A.; Santana, D.G.

2006. How and why to measure the germination process? Revista Brasileira de Botânica, 29 (1): 1-11.

Rejila, S.; Vijayakumar, N.

2011. Allelopathic Effect of Jatropha curcas on Selected Intercropping Plants (Green Chilli and Sesame). Journal of Phytology, 3 (5): 1-3.

Sahoo, K.P.; Kasera, P.K.; Mohammed, S.

2012. Secondary metabolites produced during different seasons in some arid medicinal plants. Asian Journal of Plant Science and Research, 2 (6): 650-652.

Sokal, R.R.; Rohlf, F.J.

1997. Biometry: the principles and practice of statistics in biological research. New York: W. H. Freeman, 158 pp.

Taiz, L.; Zeiger, E.

2006. Fisiologia vegetal. $3^{a}$ ed. Porto Alegre: Artmed, 719 pp.

Yoshimura, H.; Sawa, Y.; Tamotsu, S.; Sakai, A.

2011. 1,8-cineole inhibits both proliferation and elongation of by-2 cultured tobacco cells. Journal of Chemical Ecology, 37 (3): 320-328. 